\title{
Salmonellosis in a young Amazonian manatee (Trichechus inunguis)
}

\author{
José de Jesus Correa Neto ${ }^{1}$ (i) Rosekelly de Jesus Cardoso ${ }^{1}$ (D) \\ Natalia Maxine Ferreira Pinheiro Sarmento ${ }^{1}$ Gabriela Riet-Correa ${ }^{*}$ (iD) Pedro Soares Bezerra Júnior ${ }^{1}$ () \\ Carina Martins de Moraes ${ }^{1}$ (i) Alexandra Fernandes Costa ${ }^{1}$ (i) Renata Emin-Lima ${ }^{2}$ (i) \\ Valiria Duarte Cerqueira ${ }^{1}$
}

${ }^{1}$ Programa de Pós-graduação em Saúde Animal da Amazônia, Instituto de Medicina Veterinária, Universidade Federal do Pará (UFPA), 68740-970, Castanhal, PA, Brasil. E-mail:griet@ufpa.br. "Corresponding author.

${ }^{2}$ Museu Paraense Emílio Goeldi, Belém, PA, Brasil.

ABSTRACT: The objective of this study was to describe a case of salmonellosis in an Amazonian manatee (Trichechus inunguis). The animal was rescued from a tributary of the Capim River, in the municipality of Goianésia do Pará, Pará, Brazil, kept in a pool, and died approximately five months after being rescued. The main changes observed at necropsy were that the cecum and colon had serosal hyperemia, wall edema, thickened mucosa with ulcerated areas and covered by a thin layer of fibrin, and a yellowish liquid content. Histologically, there was moderate multifocal fibrinonecrotic typhlocolitis associated with intense bacterial colonization. Salmonella enterica subsp. enterica (rough) was isolated in cecum and colon fragments. This is the first report of salmonellosis in an Amazonian manatee.

Key words: sirenians, Salmonella enterica subsp. enterica, Amazon.

Salmonelose em um filhote de peixe-boi-da-amazônia (Trichechus inunguis)

RESUMO: O objetivo deste trabalho é descrever um caso de salmonelose em um peixe-boi-da-amazonia (Trichechus inunguis). O animal foi resgatado em um afluente do rio Capim, no município de Goianésia do Pará, Pará, Brasil, sendo mantido em uma piscina e morrendo aproximadamente cinco meses após o resgate. As principais alterações observadas na necropsia foram ceco e colón com hiperemia da serosa; edema da parede; mucosa espessada, com áreas ulceradas e revestida por uma fina camada de fibrina; e conteúdo líquido amarelado. Histologicamente havia tiflocolite fibrinonecrótica, multifocal, moderada, associada a intensa colonização bacteriana. Em fragmentos de ceco e cólon foi isolada Salmonella enterica subsp. enterica (rugosa). Este é o primeiro relato de salmonelose em peixe-boi-da-amazônia. Palavras-chave: sirênios, Salmonella enterica subsp. enterica, Amazônia.

The Amazonian manatee (Trichechus inunguis) is an herbivorous aquatic mammal occurring throughout the Amazon basin, from Colombia, Peru, and Ecuador to the Marajó Island in Brazil. Of all members of the order Sirenia, the Amazonian species is the only one to occur in fresh water (ROSAS \& PIMENTEL, 2001).

Zoonotic pathogens can affect the health of aquatic mammals and, among them, bacteria of the genus Salmonella play an important role in causing disease in these animals (VERGARA-PARENTE et al., 2003). Reports of salmonellosis mortality in manatees in Brazil are rare, with only one report of salmonellosis in a manatee calf (Trichechus manatus manatus) stranded on the coast of Ceará (VERGARA-
PARENTE et al., 2003). The objective of this study was to describe a case of salmonellosis in a young Amazonian manatee (T. inunguis).

On August 26, 2015, a female Amazonian manatee calf ( $T$. inunguis) measuring $0.80 \mathrm{~m}$ and weighing $15 \mathrm{~kg}$ was reported in a tributary of the Capim River, in Goianésia do Pará, Pará, Brazil (035' 55.33" S, 48 54'3.56" W), in a shallow area, floating and disoriented. The calf was rescued, kept in a swimming pool, and received four $750 \mathrm{ml}$ bottles of soy milk and canola oil daily. Approximately five months after being rescued, the animal began to present an arched position, suggesting abdominal pain, and absence of defecation. On December 16, 2015, during transport to a rehabilitation center, the 
animal died and underwent necropsy at the Animal Pathology Laboratory of the Federal University of Pará (Universidade Federal do Pará, UFPA). Fragments of various organs were collected and fixed in $10 \%$ formalin, processed routinely for histology, before being embedded in paraffin, cut into $5 \mu \mathrm{m}$ slices, and stained with hematoxylin and eosin (H\&E). Colon, cecum, gallbladder, and liver fragments were collected and sent under refrigeration to the Microbiology Laboratory of the UFPA, where the samples were seeded by depletion in blood agar supplemented with 5\% equine blood and MacConkey agar. The seeded plates were incubated at $37^{\circ} \mathrm{C}$ for 48 hours. The colony forming units (CFU) were isolated and sent to the Laboratory of Enterobacteria (Laboratório de Enterobacteria, LABENT) of the Oswaldo Cruz Foundation (Fundação Oswaldo Cruz, FIOCRUZ), Rio de Janeiro, for identification.

At necropsy, there was a predominance of large intestinal changes. The cecum and colon had serosal hyperemia and wall edema, and the lumen was filled with a yellowish liquid content, found predominantly in the cecum and initial third part of the colon. The mucosa of these segments was thickened, covered with a thin layer of fibrin (Figure 1A), and showed areas of ulcerations. Dry feces and mucosal thickening in the final third part of the colon were also observed (Figure 1B). The gallbladder presented yellowish multifocal areas, measuring approximately $1 \mathrm{~mm}$ in diameter (Figure 1C). Histologically, the cecum and colon presented areas of crypt-denuded mucosal necrosis, moderate inflammatory infiltrate of lymphocytes, macrophages, plasma cells, and neutrophils, cellular debris, fibrin deposition, and intense bacterial colonization, characterized by the presence of basophilic coccobacillus. The liver presented discrete, randomly distributed multifocal areas of mononuclear infiltrate, consisting predominantly of macrophages. Salmonella enterica subsp. enterica (rough) was isolated from the samples and sent to FIOCRUZ for identification.

The diagnosis of salmonellosis in the present study was based on the pathological findings and isolation of $S$. enterica subsp. enterica (rough) from the intestine. The observed acute, moderate,

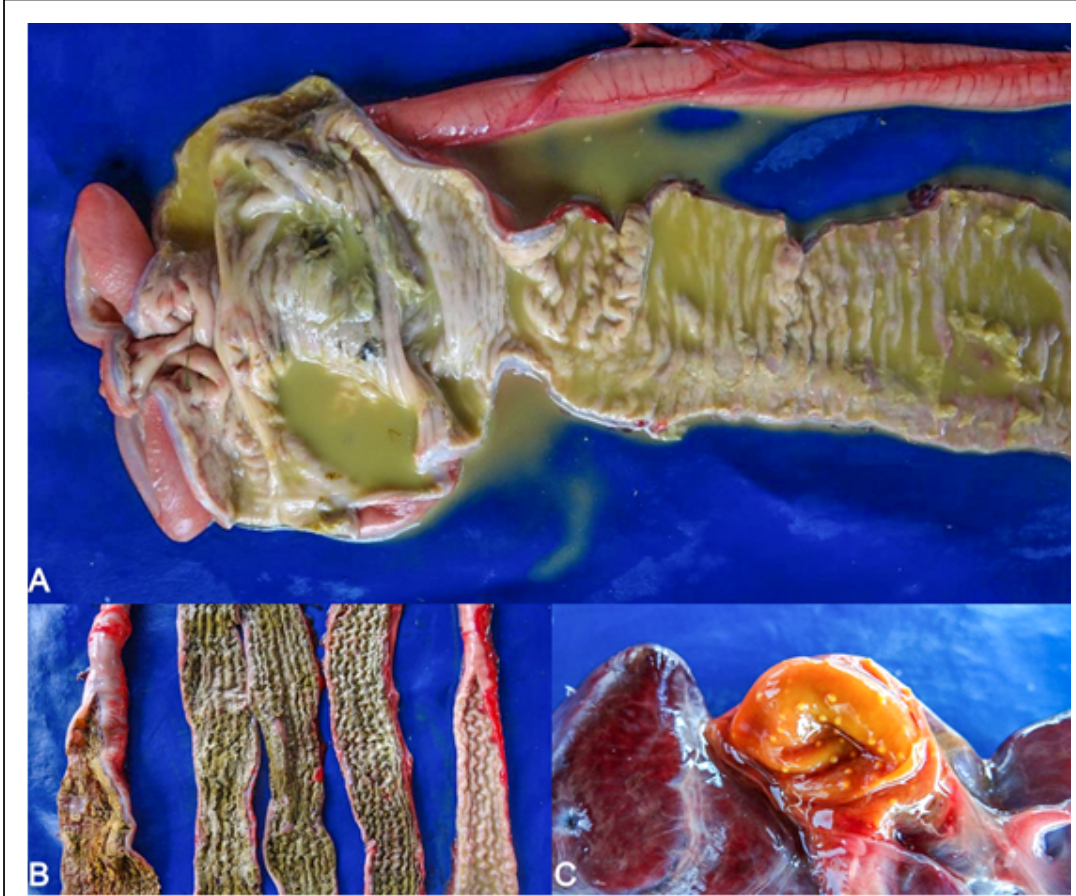

Figure 1 - Salmonellosis in a young Amazonian manatee (Trichechus inunguis). A. Cecum and colon. The mucosa is thickened, covered with a thin layer of fibrin, with a yellowish liquid content. B. Colon. Thickened mucosa, with fibrin in the middle of dry feces. Thickening of the wall is observed due to edema. C. Gallbladder. Presence of yellowish multifocal areas in the mucosa. 
and multifocal fibrinonecrotic typhlocolitis is characteristic of enteric salmonellosis. This bacterium is an important cause of acute and chronic diarrhea and death in several animal species, as well as humans (GELBERG, 2018). Intestinal and hepatic lesions observed in our study were similar to those described in sirenians (ELLIOTT et al., 1981; OWEN et al., 2018) and other mammal species with salmonellosis (ZACHARY, 2013).

Salmonella spp. are widely distributed in nature, with humans and animals as being their main natural reservoirs (SHINOHARA et al., 2008). Salmonella live in the digestive tract of vertebrate animals and, like many pathogens, cause no harm when occurring in small numbers in a balanced environment. When there is a change in immunity or in the intestinal microbiota, the bacteria can proliferate and cause disease (TIZARD et al., 2004). In wild animals, combating bacteria in natural environments and in captivity is a major challenge (SHINOHARA et al., 2008). Many clinically healthy animals can be asymptomatic hosts of Salmonella, silently spreading the bacteria in the environment in which they live (SANCHEZ et al., 2002).

Although, the source of infection was not determined, several factors may have contributed to the establishment of the disease. The calf was found without its mother struggling in the shallowest part of a small, shallow river. There was no information on whether its colostrum intake was adequate or not. The colostrum of the Amazonian manatee has a high amino acid content, which extremely important in the first 48 hours of life for developing the calf's immune system, and protecting the animal against infectious agents (BARBOSA, 2016). The stress conditions imposed in captivity, such as artificial feeding and greater variations in water temperature, may have led to decreased immunity and contributed to the establishment of the disease. In addition, the calf was kept in a swimming pool in which the water was only changed every 48 hours due to little water availability. The delay in changing the water may have contributed to an increased amount of pathogens in the pool water, thus enhancing infection by an excess of pathogens ingested.

Another factor to consider is that birds had free access to the pool where the calf was kept, which could also have been a source of infection. Humans and most domestic and wild animals, including birds, reptiles, and insects, may be infected with Salmonella or become a carrier, and may contaminate the environment, drinking water, and food through their feces (CAMPOS, 2015).
As for marine mammals, salmonellosis has been reported in sirenians (ELLIOTT et al., 1981; VERGARA-PARENTE et al., 2003; VORBACH et al., 2017), cetaceans (GRATTAROLA et al., 2019), and pinnipeds (STROUD \& ROELKE, 1980). There are only three reports of this disease in sirenians, namely a case of salmonellosis by $S$. lohbruegge in a dugong (Dugong dugon) kept in captivity in Australia (ELLIOTT et al., 1981); a case of salmonellosis by $S$. panama in a manatee ( $T$. manatus manatus) rescued from being stranded on the west coast of Ceará, in Brazil, which was then held in captivity for 25 days (VERGARA-PARENTE et al., 2003); and a case of septicemia by $S$. enterica in a free-living Florida manatee (Trichechus manatus latirostris) found stranded on the Atlantic coast of Florida, in the United States (VORBACH et al., 2017). This is the first report of salmonellosis in an Amazonian manatee.

Although, salmonellosis is a disease little reported in aquatic mammals, Salmonella enterica is a zoonotic pathogen frequently isolated from free-living marine mammals worldwide, especially pinnipeds (STODDARD et al., 2008). Immune system impairment caused by stress or transport can change the intestinal microbiota balance, which can lead to salmonellosis, and is usually severe in young animals (GELBERG, 2018). In the present study, the observed changes, characterized by acute injuries, suggest that the calf developed the disease during captivity.

Enterocolitis, secondary to intestinal tract impairment, due to an artificial diet and debilitation by immunosuppression was reported in orphaned manatees in rehabilitation, with Pseudomonas aeruginosa, Salmonella spp., and Clostridium difficile (OWEN et al., 2018) being isolated in these cases. The detection of infectious diseases in these animals provides important information about the aquatic ecosystem and public health, since many species of marine mammals share the habitat with humans, and are efficient sentinels for zoonotic infectious agents (BOSSART, 2011, GRATTAROLA et al., 2019).

The present study demonstrated that $S$. enterica was the cause of death in an Amazonian manatee and should be considered in the differential diagnosis of other gastrointestinal diseases that can affect captive manatees, such as infection by $P$. aeruginosa and C. difficile (OWEN et al., 2018).

\section{ACKOWLEDMENTS}

The authors thank CAPES for the master's (Process: 1664189) and postdoctoral grant; CNPq (Process 313356/2015-7); and LABENT/FIOCRUZ for the microbiological analysis. 


\section{BIOETHICS AND BIOSSECURITY COMMITTEE APPROVAL}

ICMBio-SISBIO.

This study was authorized under number 38130-1

\section{DECLARATION OF CONFLICT OF INTERESTS}

The authors declare no conflict of interest. The founding sponsors had no role in the design of the study; in the collection, analyses, or interpretation of data; in the writing of the manuscript, and in the decision to publish the results.

\section{AUTHORS' CONTRIBUTIONS}

NREL, AFC, RJC, and NMFP rescued and monitored the manatee during captivity. GRCR, VDC, CMM, PSBJ, and JJCN performed the necropsy and laboratory analysis. GRCR, VDC, PSBJ, RJC, NMFP, and JJCN prepared the manuscript draft. All authors critically reviewed the manuscript and approved the final version.

\section{REFERENCES}

CAMPOS, L. C. Salmonella. In: TRABULSI, L.R.; ALTERTHUM F. Microbiologia, $6^{\circ}$ Ed., São Paulo: Atheneu, 2015, Cap.43, p.351-360.

ELLIOTT, H. et al. A fatal case of salmonellosis in a dugong. Journal of Wildlife Diseases. Vol.17, N.2, p.203-208, 1981. Available from: $<$ https://www.jwildlifedis.org/doi/abs/10.7589/0090-355817.2.203>. Accessed: Aug. 05, 2019.

GELBERG, H. B. Sistema digestório, peritônio, omento e cavidade peritoneal. In: ZACHARY, J.F. Bases da patología em veterinária. São Paulo: Elsevier, 2018, $6^{\circ}$ Ed., Cap.7, p.324-411.

GRATTAROLA et al. First report of salmonella 1,4,[5],12:i:- in freeranging striped dolphins (Stenella coeruleoalba), Italy. Nature. v.9, n.6061, p.1-14, 2019. Available from: $<$ https://www.nature.com/ articles/s41598-019-42474-6>. Accessed: Aug. 05, 2019.
OWEN, H. et al. Sirenia. In: TERIO, K. A.; McAlOOSE, D.; LEGER, J. ST. Patology of wildlife and zoo animals. Elsevier. 2018. Cap.24, p.600

ROSAS, F. C. W; PIMENTEL, T. L. Order Sirenia (Manatees, Dugongs, Sea Cows). In: STODDARD, R. A. et al. Prevalence and characterization of Salmonella spp. among marine mammals in the Channel Islands, California. Diseases of Aquatic Organisms. 2001; v.81, p.5-11, 2.

SANCHEZ, S. C. L. Animal sources of salmonellosis in humans. Journal of the American Veterinary Medical Association. vol.221, n.4, p.492-497, 2002. Available from: <https://doi. org/10.2460/javma.2002.221.492>. Accessed: May, 01, 2020

SHINOHARA, N. K. S. et al. Salmonella spp., Importante agente patogênico veiculado em alimentos. Ciência \& saúde coletiva. vol.13, n.5, p.1675-1683, 2008. Available from: $<$ https://doi.org/10.1590/S1413-81232008000500031>. Accessed: Aug. 08, 2019.

STROUD, R. K.; ROELKE, M. E. Salmonella meningoencephalomyelitis in a northern fur seal (Allorhinus ursinus). Journal of Wildlife Diseases. Vol.16, n.1, 1980. Available from: $<$ https://www.jwildlifedis.org/doi/pdf/10.7589/0090-355816.1.15>. Accessed: Aug. 05, 2019.

TIZARD, I. Salmonellosis in wild birds. Seminars in Avian and Exotic Pet Medicine. vol.13, n.2, p.50-66, 2004. Available from: <https://doi.org/10.1053/j.saep.2004.01.008>. Accessed: May, 20, 2020.

VERGARA-PARENTE, J. E. et al. Salmonellosis in an Antillean manatee (Trichechus manatus manatus) calf: a fatal case. Aquatic Mammals. v.29, p.131-136, 2003

VORBACH, B. S. et al. Fatal systemic Salmonellosis in a Florida Manatee (Trichechus manatus latirostris). Journal of Wildlife Diseases. v.53, n.4, p.930-933, 2017. Available from: <https:// www.jwildlifedis.org/doi/pdf/10.7589/0090-3558-16.1.15>. Accessed: Aug. 01, 2019.

ZACHARY, J. F. Mecanismo das infecções microbianas. In: ZACHARY, J. F. Bases da Patologia em Veterinária. Rio de Janeiro: Elsevier. 6 a ed., 2018, cap.4, p.159. 